\title{
An empirical study on the relationship of purchasing a chocolate based on its packaging
}

\author{
Yasaman Giyahi*
}

Department of Accounting \& Management of Allameh Tabatabai University, Tehran, Iran

\begin{tabular}{|c|c|}
\hline A R T I C L E I N F O & A B S T R A C T \\
\hline $\begin{array}{l}\text { Article history: } \\
\text { Received October 10, } 2011 \\
\text { Received in Revised form } \\
\text { November, 14, } 2011 \\
\text { Accepted 25 November } 2011 \\
\text { Available online } \\
\text { 4 December 2011 } \\
\text { Keywords: } \\
\text { Packaging } \\
\text { Chocolate } \\
\text { Grantor of Gift } \\
\text { Recipient of Gift }\end{array}$ & $\begin{array}{l}\text { Chocolate is one of popular gifts among people in many societies. Packaging of such product } \\
\text { plays an important role on marketing this item and the primary question of this survey is to } \\
\text { determine the impact of packaging on better introducing a product. The inference statistical } \\
\text { tests show that packaging is an important item in selection of chocolate as a gift. Percentage of } \\
\text { chocolate is the most important information on packaging and color of packaging is of } \\
\text { paramount significance when customers purchase chocolate for individuals with official } \\
\text { relationship. In this paper, we present an empirical study to measure the effects of chocolates' } \\
\text { packaging on purchasing them. The proposed study of this paper designs a questionnaire and } \\
\text { distributes them among different people. The results are analyzed using some non-parametric } \\
\text { tests and they are discussed. The preliminary results indicate that the number of purchased } \\
\text { packages within a year, cost of purchasing chocolate within a year, type of relationship of } \\
\text { recipients of chocolate as gift, gender of recipient of chocolate as gift, age group of recipient of } \\
\text { gift, type of store, nationality of chocolate, significance of packaging in various price ranges, } \\
\text { type of packaging, insertion of information on package and color of packaging, are important } \\
\text { factors influencing people to buy more. }\end{array}$ \\
\hline
\end{tabular}

\section{Introduction}

In tandem with all problems, where various industries are grappling with it, confectionary, sweet and chocolate industry also is facing various problems and shortfalls. Type of packaging confection, sweet and chocolate are some of the problems, facing this industry, which makes a difference between domestic products and foreign rivals. Despite noticeable and eye-catching progresses observed in packing products of this industry in recent years, there is a wide qualitative gap between packaging of domestic products with foreign ones. Major part of these gaps is associated with the graphic design of these products while the other part is related to the type of material used in packaging operations (Alizadeh, 2011). With regard to the confection, sweet and chocolate, it should be confessed that market of these products is growing severely in the Middle East region. Traditionally, people of this region show vehement interest in various types of chocolate and

* Corresponding author. Tel.: 00989123764259

E-mail addresses: ysmn.giahi@gmail.com (Y. Giyahi) 
confection. For many years, confection and chocolate have been of paramount importance as a gift in the Middle East.

The attraction of packaging can be defined as the art of establishing relationship, boosting awareness, willing to purchase, preferring a definite brand name and finally performing of shopping (Alavi, 2005). Today, packaging is not merely used for preserving goods and commodities anymore, rather, roles and responsibilities are considered for it such as bringing about value added coupled with giving information and also prestige to purchaser. Packaging needs to attract customer, bring attractiveness, and safeguard dignity and personality of customers as well. In addition, packaging should meet the following criteria (Ebrahimi, 2007):

- To honor consumer,

- To consider culture and values in target country,

- To use a culture that is enjoyable to all people.

The following are some of the factors, which cause significance of packaging as a marketing tool: (Feyz \& Salahshour, 2008)

1. Media new habits and role of creating trade name by media-related publicity,

2. Significance of decision makings of purchase at store (suddenly decision making),

3. Structural changes inside retail sellers which has affected whole supply chain and also has caused creation of new demands in distribution system,

4. Boosting awareness of management on using packaging as a tool for differentiating and creating identity for consumable goods and commodities.

Bear in mind that packaging is one of the most effective factors in selling goods and commodities. Generally speaking, appropriate packaging plays a leading role in selling goods easily. Moreover, specifying appearance of goods, packaging also determines its amount and price. Today, many consumable products are supplied to the consumer market with the packages, which attract and fascinate customer. Some marketers believe that packaging is one of the most important and strategic factors in marketing. In some cases, packaging is considered as one of the most powerful supply tools. In other words, appropriate and sound packaging of a product will cause supplier to sell his products easily at consumer market. There are many evidences at hand that packaging will play a key role in future in consumer market, the most important factors are as follows (Ebrahimi, 2007):

1. Juvenility of nations and also changes in consumption tastes,

2. Assuming distribution of products economically in packaging,

3. Accelerating in the field of supplying and distributing.

Various purchasers adopt different assumptions with regard to their age, gender, economic, social and cultural situation and even their geographic situation on the goods, which are displayed to them. Some people pay due attention to the economic alternatives like quantity and price of goods while some people think about quality or unique specifications of goods. In the same direction, reputability of goods and name and prestige of producer or brand name of goods are of paramount importance to some other people. The more gender, age and social and economic situation of consumers is recognized, the more packaging will be operated fairly in consumer market (Kermaninejad, 2006).

Using them with the aim of spreading trend of relationship between human beings is one of the stimulating reasons for creating various packages. A good package can carry news and declare specific statement and/or convey special feeling. In other words, packages can bond relationship among people. What can be said categorically is that all packages, ranging from ordinary to masterly designed packages, convey partial and slight news more or less and such conveyance of news is associated with many products (Alavi, 2005). The issue will be signified when purchaser buys a product as a gift. Criteria of purchase and strategies of consumers' shopping vary when they want to 
purchase a present for someone and when they want to purchase product for themselves. Consumers purchase gift for various reasons and occasions. In social expectations and occasional situations, it seems necessary that some gifts should be offered irrespective of real tendencies of grantor of gift. Gifts are granted with the aim of declaring a type of feeling. Type of gift varies based on gender and situation and will affect behavior of purchaser and relationship between grantor of gift and recipient of gift. Sometimes, price of gift indicates a kind of respect that grantor of gift considers for its recipient. Image and function of gift indicates implication of grantor of gift from image and personality of recipient of gift. In addition, function of gift reflects image and contemplation of grantor of gift. Nature of a gift can indicate kind of relationship of grantor of gift with its recipient. The operation of granting and receiving gift can change relationship between grantor and recipient of gift. The items or goods, which are received as gift, almost convey some meanings with regard to the relationship of the two sides i.e. recipient or grantor of gift. Of course, cultural specifications are effective in this respect (Hawkins et al., 2007).

Concentration of this article lies on the study, which deals with the effect of packaging chocolate on selection of chocolate as a gift. Solid chocolate was made in 1800 (A.D) for the first time. Joseph Fry was the first person who supplied today chocolate in 1847, aimed at being appropriate and suitable for eating easily. In 1868, a person named Swiss-born "Daniel Peter" supplied the first milky chocolate. He used powdered milk for the provision of various types of chocolates. His neighbor "Henry Nestle" who possessed child food production factory, help him remarkably in provision of powdered milk. Today, chocolate has a special status in food basket of European countries. Generally, chocolate is of paramount significance in food basket of European states. In our country, chocolate is yet considered as a luxury goods. (Derakhshan, 2011).

\subsection{Packaging}

As one of the most important and determining effective factors in global markets, packaging industry has presently attracted the attention of all production, trade and commercial activities of world to itself. Packaging is not a new concept in industry and economy; rather, it is a developed industry and it has attained remarkable progresses and achievements in recent years according to the market requirements. Specifying product and assuring health of product in the course of movement in distribution system is regarded as a basic role and performance of packaging which will reach to consumer at last. This type of packaging with such objective will not add value of product. Impact on price of goods is considered as criterion of success merely. At any rate, if packaging is caused facilitation of using product, and/or can be reused from that packaging, then, a partial amount can be added to the price of goods with the aim of justifying cost price and advancement of sale. It is for centuries that packaging is considered as a necessary element for using and safeguarding goods. Today, particularly in retail selling sector, all products are supplied in packed form. Hence, packaging is a basic part of social - economic system and forms an important cycle between industry and trade on one hand and consumer on the other hand (Sharifi, 2010).

Packaging is tantamount to coating, cover or clothes of product and purchaser can guess level of quality, price, type of content, material and its function while observing package of product for the first time (Feyz \& Salahshour, 2011). Packaging is an important factor, which influences perception of consumers and intention of purchasing product. Moreover, good packaging will boost expectations among consumers. Then, producer should able to create appropriate expectations among consumer with regard to a product (Ares \& Deliza, 2010). In a nutshell, packaging will make product. A good and fair product in average or low-quality package will have not a good sale ratio, unless, purchaser throws his/her trust on it. On the other hand, an attractive package for low-quality product will disappoint customer. If any package could attract attention of consumer but could not follow positive effects, it is useless (Firouzian et al., 2010). Both package and product should have the highest quality together. Packaging bears various duties, since most of packaging designs are set based on value of 
brand and targeting end users, view of purchasers undertakes main role of packaging industry in encouraging purchasers to purchase a product (Azizi, 2010). Hence, packaging is the origin of recognizing product and indicates quality of product and also presents information with regard to the image of brand and lifestyle of consumers (Ares et al., 2010; Dupius \& Silva, 2008). Hierarchy of Abraham Maslow can be used for studying significance of packaging (Capsule, 2008),

- Self-Actualization: Self-flourishing will turn advantage package into sentimental rewards surrounding brand and experience of owning the brand at life of an end user.

- Respect: Respect presents package of feeling of trust, confidence, superiority and success of brand and will establish relationship with customer with very sensitive methods.

- Dependency: Dependency introduces package of product and brand to establish relationship with a great number of various walks of life and also establishes relationship between individual and community.

- Safety: Safety protects package of product and will reduce probability of damaging it.

- Physiologic: Physiologic contains package of all sectors, documents for using product i.e. basic sections.

\subsection{Chocolate packaging}

Consumers may think of chocolate packaging but what will actually convince them to purchase chocolate is: observing the very product i.e. chocolate. In some cases, most of them may not approve packaging, consciously. Undoubtedly, a good packaging of chocolate can force purchasers to purchase chocolate. Such good packaging improves mental image of a product. Packaging helps increase of value of chocolate and can reflect quality of contents inside package. Generally, a good packaging can affect way of feeling of customer on his mental imagination from product.

Mostly, type of designing package determines price of product. However, the most important of which is the confidence that customers want to know about quality of purchased goods. Packaging helps improvement of this mentality. Packaging is a part of product, which could be manifested the same as a gift and chocolate is granted as gift more than that of being used as personal consumption.

Chocolate producers are required to know about the whole packaging and also way of granting chocolate as gift to someone and to whom this product will be granted. In addition, chocolate producers should also think of contemplative procedure of customer on this product (Sectzer, 2002).

The discussion lies on perception of customers. Adoption of change on these perceptions can convince them to pay more money. Packaging can establish such mentality and also can bring about value added for product inside package. When packaging follows attractive appearance, making decision is facilitated for customer and will result in selling product. Both appearance of packaging and components of packaging play a leading role in this respect (Sectzer, 2002).

\section{Research methodology}

After studying theoretical basics at the present study within framework of field study, an opinion poll was made from chocolate purchasers in the field of effect of packaging chocolate on selection of chocolate as gift. Accordingly, this research is of applied type in terms of objective and is of descriptive - survey type in terms of methodology.

\subsection{Main hypotheses of research}

1. Packaging chocolate is effective on its selection as gift.

2. In selection of chocolate as gift, packaging is considered as a part of gift in view of purchaser. 


\subsection{Statistical population, sample volume and sampling method}

At this study, all chocolate purchasers are considered as statistical population. Since subject of study is unlimited, the following formula was used in calculation of sample volume,

$N=\frac{Z_{\alpha / 2}^{2} P(1-P)}{\varepsilon^{2}}$

where

P: represents percentage of success at subject of study,

$\alpha$ : represents error level of sample volume,

$\varepsilon$ : represents precision of estimation.

In this study, we have $Z_{\alpha / 2}=1.96, p=0.5, \varepsilon=0.05$, which yields $N=384$.

\subsection{Designing questionnaire}

The questions of questionnaire have been outlined at three groups, which include as follows: four questions on demography (age, gender, educational level and monthly salary) with regard to purchaser at first group, seven questions on the number of gift chocolates purchased within a year, the cost spent annually for purchasing gift chocolate. Questions on: "who purchases gift chocolate in terms of type of relationship of purchaser with them, with gender and age?", "from which store these gift chocolate are purchased?" and "from which countries do these chocolates are purchased?" are categorized at the second group. Twelve questions were posed on significance of packaging, admitting of packaging as a part of gift, significance of packaging in various price ranges, situation of packaging between mark (brand name) and price, significance of packages offered in special occasions, property of packaging, designing, type of coverage, possibility of viewing inside packaging, information mentioned on it, significance of color based in type of relationship of individual with recipient of gift and priority of significance of factors of weight, size, pictorial beauty and its value in view of receiver of gift which were categorized at the third group. In summary, there are 23 questions posed at the questionnaire including multiple choice questions and five-sectional Likert Scale.

Conceptual - credit method was used for measurement of validity of questionnaire. Also, Cronbach Alpha method was used for studying reliability of questionnaire. Amount of Cronbach alpha coefficient has been obtained 0.983 for whole questionnaire. Hence, it can be concluded that the desired questionnaire enjoys acceptable reliability.

\subsection{Data analysis}

At this study, data obtained from questionnaires was analyzed through the application of SPSS software package in confidence level (95\%). Descriptive statistics and inference statistics, including Kolmogorov-Smirnov test, One-way T student test, Binominal test, Two-way ANOVA $T$ student paired comparisons and Friedman test have been used for data analysis.

\section{Results and discussions}

In the beginning, we will discuss the results obtained at descriptive statistics section for demographic variables of participants at the study: 
- Frequency distribution of tests based on age: below 15 years old with 1 percent, 16 to 25 years old with 24.5 percent, 26 to 35 years old with 43.2 percent, 36 to 45 years old with 15.1 percent and above 46 years old with 14.6 percent.

- Frequency distribution is shown based on gender: women with 54.7 percent and men with 37.2 percent.

- Frequency distribution based on education: Diploma and below diploma with 24.7 percent, above diploma with 11.7 percent, BA degree with 44.3 percent with MA degree or above MA degree with 16.4 percent.

- Frequency distribution is shown based on income rate: Below 5,000,000 Rials with 37 percent, 5,000,000 Rials to 10,000,000 Rials with 34.6 percent and above 10,000,000 Rials 14.3 percent.

Kolmogorov - Smirnov tests were used for studying claim posed on distribution of quantitative one variable data. Normality assumption test was used where the null hypothesis is that data are normal. This test showed that there is significance level for all indexes, equal to 0.000 and less than 0.05 error ratios. Zero assumption is rejected in 0.05 error level. Consequently, all indexes have abnormal distribution and non-parameter tests should be used for testing them. Next, we have to measure the relative importance of different items in purchasing chocolate using non-parametric tests such as binomial test, which is used for recognition of influence or non- influence of a variable in definite phenomenon. Usually, in designing hypotheses of this test, zero hypotheses indicate non-influence of variable while opposite hypothesis indicates influence of variable. Larger one-way binominal test is described as follows:

$\left\{\begin{array}{lc}H_{0}: & \text { Distribution ratio of views of individuals is found average level. } \\ H_{1}: & \text { Distribution ratio of view of individuals exceeds average level. }\end{array}\right.$ or $\quad\left\{\begin{array}{l}H_{0}: \quad p<=0.5 \\ H_{1}: \quad p>0.5\end{array}\right.$

Table 1 shows results of binominal test. Since significance level for all indicators, except indicator of "viewing contents inside box", is found smaller than error ratio (0.05), then, zero hypotheses is rejected, which indicates that this indicator is of paramount significance while purchasing chocolate as gift. However, for indicator "viewing contents inside box", since significance level of one-way test exceeds error ratio (0.05), then, zero hypothesis s not rejected. That is to say that "viewing contents inside box" is not much more important while purchasing chocolate as gift.

\section{Table 1}

Binominal Test Results of Research Indicators

\begin{tabular}{lr}
\hline Indicator & Test Result (Significance level =0.05) \\
\hline Effect of packaging chocolate on its selection & Reject \\
\hline Packaging as a part of gift & Reject \\
\hline Significance of packaging & Reject \\
\hline Design on package & Reject \\
\hline Packaging that keeps chocolate fresh. & Reject \\
\hline Viewing contents inside gift box & Accept \\
\hline Insertion of information on package in terms of type of chocolate (toffee, pure chocolate, etc.) & Reject \\
\hline Insertion of information on package in terms of picture of chocolate inside box & Reject \\
\hline Insertion of information on package in terms of constituent materials or ingredients of chocolate & Reject \\
\hline Insertion of information on package in terms of percentage of chocolate & Reject \\
\hline Significance of color of packaging while purchasing for a friend & Reject \\
\hline Significance of color of packaging while purchasing it for family members & Reject \\
\hline Significance of color of packaging while purchasing it for relatives & Reject \\
Significance of color of packaging while purchasing for those individuals with official relationship & Reject \\
\hline
\end{tabular}

Friedman test is used for studying equality of prioritizing (ranking) of a number of dependent variables. Zero hypothesis states that mean of rating is found equal and opposite hypothesis declares that there are at least two factors which have different rating. Of course, it should be noted that there 
is not a method for rating in statistics and Friedman Test can only deal with studying equality of rating. Table 2 summarizes the results of our test.

$\begin{cases}H_{0}: & \text { Mean of rating of all variables are equal. } \\ H_{1}: & \text { There are at least two variables with different rating average. }\end{cases}$

Table 2

Results of Ranking

\begin{tabular}{|c|c|c|}
\hline Indicator & Mean & Rank \\
\hline Insertion of information on package in terms of percentage of chocolate & 2.64 & 1 \\
\hline $\begin{array}{l}\text { Insertion of information on package in terms of type of chocolate (toffee, pure } \\
\text { chocolate, etc.) }\end{array}$ & 2.59 & 2 \\
\hline $\begin{array}{l}\text { Insertion of information on package in terms of its constituent materials } \\
\text { (ingredients) }\end{array}$ & 2.43 & 3 \\
\hline Insertion of information on package in terms of photo of chocolate inside box & 2.34 & 4 \\
\hline Indicator & Mean & Rank \\
\hline $\begin{array}{l}\text { Significance of color of package while purchasing for individuals with official } \\
\text { relationship }\end{array}$ & 2.74 & 1 \\
\hline Significance of color of packaging while purchasing for a friend & 2.7 & 2 \\
\hline Significance of color of packaging while purchasing for family members & 2.34 & 3 \\
\hline Significance of color of packaging while purchasing for relatives & 2.22 & 4 \\
\hline Indicator & Mean & Rank \\
\hline Effect of packaging chocolate on its selection & 8.76 & 1 \\
\hline Insertion of information on package in terms of percentage of chocolate & 8.42 & 2 \\
\hline $\begin{array}{l}\text { Insertion of information on package in terms of type of chocolate (toffee, pure } \\
\text { chocolate, etc.) }\end{array}$ & 8.24 & 3 \\
\hline Packaging as a part of gift & 8.01 & 4 \\
\hline Design on package & 7.92 & 5 \\
\hline $\begin{array}{l}\text { Significance of color of packaging while purchasing for the individuals with official } \\
\text { relationship }\end{array}$ & 7.87 & 6 \\
\hline Packaging which keeps chocolate fresh. & 7.82 & 7 \\
\hline Insertion of information on package in terms of its constituent materials ingredients) & 7.71 & 8 \\
\hline Significance of color of packaging while purchasing for a friend & 7.66 & 9 \\
\hline Insertion of information on package in terms of photo of chocolate inside box & 7.33 & 10 \\
\hline Significance of packaging & 6.61 & 11 \\
\hline Significance of color of packaging while purchasing for family members & 6.42 & 12 \\
\hline Viewing contents inside box & 6.24 & 13 \\
\hline Significance of color of packaging while purchasing for relatives & 5.99 & 14 \\
\hline
\end{tabular}

Chi Square test states whether frequency of various classes are equal to each other or not? Results of this test, for those indicators that their measurement is nominal i.e. number of purchased packages within a year, cost of purchasing chocolate within a year, type of relationship of recipients of chocolate as gift, gender of recipient of chocolate as gift, age group of recipient of gift, type of store, nationality of chocolate, significance of packaging in various price ranges, type of packaging, insertion of information on package and color of packaging, shows that zero hypothesis is rejected for all indicators in significance level (0.05). That is the frequency of observations is not equal in various classes. We refer to the indicators' frequency table to observe frequency of definite class. Table 3 and Table 4 show the frequency of indicators, which include observed frequency, expected frequency and remaining amounts. In Table 10 and Table 11, it is specified that the number of packages, purchased by purchasers within a year, is almost less than 6 packages. In other words, purchasers buy chocolate 
less than six packs in a year. In addition, the cost spent for purchasing chocolate in a year is estimated less than 500,000 Rials.

\section{Table 3}

No. of Packages Purchased within a Year

\begin{tabular}{llll}
\hline & Observed Frequency & Expected Frequency & Remained \\
\hline Less than six packages & 245 & 127.7 & 117.3 \\
6 to 12 packages & 112 & 127.7 & -15.7 \\
More than 12 packages & 26 & 127.7 & -101.7 \\
\hline Total & 383 & & \\
\hline
\end{tabular}

Table 4

Cost of Purchasing Chocolate within a Year

\begin{tabular}{lccc}
\hline & Observed Frequency & Expected Frequency & Remained \\
\hline Less than 500,000 Rials & 233 & 96.0 & 137.0 \\
From 500,000 Rials to 1,000,000 Rials & 107 & 96.0 & 11.0 \\
From 1,000,000 Rials to1,500,000 Rials & 33 & 96.0 & -63.0 \\
More than 1,500,000 Rials & 11 & 96.0 & -85.0 \\
\hline \multicolumn{1}{c}{ Total } & 384 & & \\
\hline
\end{tabular}

As we can observe from the results of Table 5 and Table 6, Individuals usually give present to their friends where their gender almost is female. Individuals usually offer chocolate as gift to those who are from 26 to 35 years old and the results are summarized $n$ Table 6.

\section{Table 5}

Type of Relationship of Receivers of Chocolate

\begin{tabular}{lccc}
\hline & Observed & Expected & Remained \\
\hline Friend & 261 & 139.0 & 122.0 \\
Family members & 99 & 139.0 & -40.0 \\
Relatives & 109 & 139.0 & -30.0 \\
The individuals whom you have official relationship with them. & 87 & 139.0 & -52.0 \\
\hline Total & 556 & & \\
\hline
\end{tabular}

\section{Table 6}

Gender of Receivers of Chocolate

\begin{tabular}{cccccccc}
\hline Gender & Frequency & Frequency & Remained & Age & Frequency & Frequency & Remained \\
\hline Women & 214 & 126.7 & 87.3 & Below 15 years & 80 & 113.6 & -33.6 \\
Men & 143 & 126.7 & 16.3 & From 15 to 25 years & 162 & 113.6 & -48.4 \\
Unanswered & 23 & 126.7 & -103.7 & From 26 to 35 years & 203 & 113.6 & 89.4 \\
\hline Total & 380 & & & From 36 to 45 years & 89 & 113.6 & -24.6 \\
\hline
\end{tabular}

Individuals almost provide chocolate from the stores which are merely considered as supplier of chocolate and then from confectioneries, and sweet shops (Table 7). Usually, the chocolates that are purchased as gift are both Iranian and non-Iranian ones. Most of them are non-Iranian chocolates (Table 8). Most individuals pay due attention to packaging of chocolate ranging from 150,000 to 300,000 Rials (Table 9).

Table 7

Type of store

\begin{tabular}{cccc}
\hline & Observed & Expected & Remained \\
\hline The stores, which are merely considered as supplier of chocolate. & 170 & 148.3 & 21.7 \\
The stores like supermarkets or food chain stores & 111 & 148.3 & -37.3 \\
Confectionaries and sweet shops & 164 & 148.3 & 15.7 \\
\hline Total & 445 & & \\
\hline
\end{tabular}


Table 8

The location of production of chocolate

\begin{tabular}{lccc}
\hline & Observed & Expected & Remained \\
\hline Iranian & 72 & 128.0 & -56.0 \\
Non-Iranian & 112 & 128.0 & -16.0 \\
Both of them (Iranian and Non-Iranian) & 200 & 128.0 & 72.0 \\
\hline Total & 384 & & \\
\hline
\end{tabular}

\section{Table 9}

Significance of packaging in various price ranges

\begin{tabular}{lccc}
\hline & Observed & Expected & Remained \\
\hline Less than 150,000 Rials & 153 & 98.5 & 54.5 \\
From 150,000 Rials to 300,000 Rials & 167 & 98.5 & 68.5 \\
From 300,000 Rials to 450,000 Rials & 42 & 98.5 & -56.5 \\
More than 450,000 Rials & 32 & 98.5 & -66.5 \\
\hline Total & 394 & & \\
\hline
\end{tabular}

In purchasing chocolate, mark (brand name), packaging and then price are of paramount significance respectively (Table 10). In terms of packaging, metallic, pasteboard and then talc (laminated gypsum) or glass packages are popular, respectively. In other words, metallic packages are first popular and then pasteboard and finally talc or glassy packages (Table 11).

Table 10

Significance of Each of Following Cases

\begin{tabular}{lccc}
\hline & Observed & Expected & Remained \\
\hline Mark & 189 & 128.0 & 61.0 \\
Packaging & 130 & 128.0 & 2.0 \\
Price & 65 & 128.0 & -63.0 \\
\hline Total & 384 & & \\
\hline
\end{tabular}

\section{Table 11}

Type of Packaging

\begin{tabular}{lccc}
\hline & Observed & Expected & Remained \\
\hline Pasteboard & 122 & 95.8 & 26.3 \\
Metallic & 143 & 95.8 & 47.3 \\
Talc or glassy packs & 107 & 95.8 & 11.3 \\
Unanswered & 11 & 95.8 & -84.8 \\
\hline Total & 383 & & \\
\hline
\end{tabular}

While purchasing chocolate as gift, its value is of paramount importance in view of receiver of gift, then, pictorial beauty, largeness of packaging size and its quantity (weight) are of paramount significance respectively (Table 12).

\section{Table 12}

Significance of each of cases

\begin{tabular}{lccc}
\hline & Observed Frequency & Expected Frequency & Remained \\
\hline QTY (weight) & 26 & 95.5 & -69.5 \\
Largeness of packaging size & 29 & 95.5 & -66.5 \\
Pictorial beauty & 128 & 95.5 & 32.5 \\
Its value in view of receiver of gift & 199 & 95.5 & 103.5 \\
\hline Total & 382 & & \\
\hline
\end{tabular}

Chi - Square test shows the following results for studying relationship between indicators:

Frequency Tables also show that most individuals purchase fewer than six packs of chocolate within a year, valued at less than 500,000 Rials, for gift (Table 13), for their friends with female gender 
(Table 14), for their friends between 15 to 35 years old (Table 15), for women between 15 to 35 years (Table 16) and they purchase Iranian and non-Iranian chocolates as gift (mostly non-Iranian chocolate) merely from the stores that are considered as supplier of chocolate (Table 17).

\section{Table 13}

Frequencies of cost for purchasing in Rials chocolate within a year

\begin{tabular}{cccccc}
\hline $\begin{array}{l}\text { No. of packages purchased } \\
\text { within a year }\end{array}$ & $\begin{array}{c}\text { Less than } \\
500,000\end{array}$ & $\begin{array}{c}500,000 \text { to } \\
1,000,000\end{array}$ & $\begin{array}{c}1,000,000 \text { to } \\
1,500,000\end{array}$ & $\begin{array}{c}\text { More than } \\
1,500,000\end{array}$ & Total \\
\hline Less than 6 packs & 204 & 36 & 4 & 1 & 245 \\
From 6 to 12 packs & 26 & 61 & 21 & 4 & 112 \\
More than 12 packs & 2 & 10 & 8 & 6 & 26 \\
\hline Total & 232 & 107 & 33 & 11 & 383 \\
\hline
\end{tabular}

Table 14

Frequencies of chocolate receivers in terms of gender

\begin{tabular}{lcccc}
\hline & Female & Male & Unanswered & Total \\
\hline Friend & 147 & 95 & 19 & 261 \\
Family members & 21 & 11 & 2 & 34 \\
Relatives & 29 & 18 & 1 & 48 \\
Individuals with official relationship & 17 & 19 & 1 & 37 \\
\hline Total & 214 & 143 & 23 & 380 \\
\hline
\end{tabular}

\section{Table 15}

Frequencies of people in terms of their age

\begin{tabular}{lcccccc}
\hline $\begin{array}{l}\text { Type of relationship of recipients of } \\
\text { chocolate }\end{array}$ & $\begin{array}{c}\text { Less than } 15 \\
\text { years }\end{array}$ & $\begin{array}{c}15 \text { to } 25 \\
\text { years }\end{array}$ & $\begin{array}{c}26 \text { to } 35 \\
\text { years }\end{array}$ & $\begin{array}{c}36 \text { to } 45 \\
\text { years }\end{array}$ & $\begin{array}{c}\text { More than } \\
46 \text { years }\end{array}$ & $\begin{array}{c}\text { Total } \\
\text { Friend }\end{array}$ \\
Family members & 10 & 92 & 88 & 21 & 2 & 257 \\
Relatives & 6 & 34 & 10 & 40 & 4 & 98 \\
Individuals with official relationship & 10 & 28 & 57 & 10 & 6 & 107 \\
\hline Total & 80 & 162 & 203 & 89 & 18 & 86 \\
\hline
\end{tabular}

Table 16

Frequencies of chocolate receivers in terms of gender and age

\begin{tabular}{|c|c|c|c|c|c|c|}
\hline Gender & Under 15 years & 15 to 25 years & 26 to 35 years & 36 to 45 years & More than 46 years & Total \\
\hline Women & 36 & 78 & 69 & 25 & 1 & 209 \\
\hline Men & 30 & 35 & 61 & 12 & 4 & 142 \\
\hline Unanswered & 13 & 5 & 4 & 0 & 0 & 22 \\
\hline Total & 79 & 118 & 134 & 37 & 5 & 373 \\
\hline
\end{tabular}

Table 17

Characteristics of stores in terms of nationality

\begin{tabular}{ccccc}
\hline & Iranian & Non-Iranian & Both (Iranian and Non-Iranian) & Total \\
\hline The stores that are merely considered as & 12 & 74 & 84 & 170 \\
suppliers of chocolate & 24 & 21 & 47 & 92 \\
Stores like supermarkets or food chain stores & 36 & 17 & 69 & 122 \\
Confectionaries and sweet selling shops & 72 & 112 & 200 & 384 \\
\hline Total &
\end{tabular}

Based on the results we have achieved in this section, the following conclusion can be conducted.

- Information related to percentage of chocolate, its type, constituent materials (ingredients) thanks to their significance to purchasers, should be mentioned on package. 
- Appropriate color should be considered and mentioned in package designing for each group of individuals (official, friends, family and relatives) especially the first group, aimed at providing more appropriate selection for purchasers.

- Since purchasers of chocolate consider packaging as a part of gift, its design should be carried out appropriately, aimed at not to be repacked by purchaser.

- In packaging their chocolates as gift, producers should pay due attention to this point that individuals purchase chocolate less than six packs annually with the cost less than 500,000 rials. Therefore, offering very luxury and beautiful packaging with high price may reduce sales rate of their product to a great extent.

- In designing procedures for advertising, this issue should be taken into consideration that women, primarily between 26 to 35 years, constitute main recipients of chocolate as friend. Boosting attractiveness of chocolate as gift can lead to its high sales rate.

- Since chocolate are purchased and provided mainly from the chocolate-selling stores merely, commissioning chain stores, special of each chocolate $\mathrm{mfg}$. unit, and also distribution of chocolates at these stores can boost sales rate of chocolate to a great extent.

- Metallic packaging of chocolate has been prioritized than any other packaging. Hence, producers can give variety and changes on metallic packaging of their products.

- Since purchasers consider value of received chocolate in view of receiver of chocolate, producers should pay due attention to this point that the chocolate which they offer to someone should associate with its price.

\section{Conclusions}

In this paper, we have presented an empirical study to find the important factors influencing packaging Chocolate products sold in Iran. The proposed study of this paper has designed a questionnaire and distribute them among different people. The results were analyzed using some nonparametric tests and they were discussed. The number of purchased packages within a year, cost of purchasing chocolate within a year, type of relationship of recipients of chocolate as gift, gender of recipient of chocolate as gift, age group of recipient of gift, type of store, nationality of chocolate, significance of packaging in various price ranges, type of packaging, insertion of information on package and color of packaging, are important factors influencing people to buy more.

\section{References}

Alavi, M. (2005). Study of impact of packaging Choco Pars products on decision making of purchasers. Islamic Azad University of Central Tehran Branch: Master of business Administration (MBA).

Alizadeh, A. (2011). Maa Chocolate and their Chocolates. Packaging. $6^{\text {th }}$ Edition. No. 61. 34-45

Ares, G. \& Deliza, R. (2010). Identifying important package features of milk desserts using free listing and work association. Food Quality and Preference, 21(6), 621-628.

Ares, G., Besio, M., Gimenez, A. \& Deliza, R. (2010). Relationship between Involvement and Functional Milk Desserts Intention to Purchase, Influence on Attitude towards Packaging Characteristics. Appetite. 55. 298 - 304.

Azizi, A. (2010). Effect of Packaging on Market Developments. (In Farsi), $5^{\text {th }}$ ed., 54, 52-57

CAPSULE (2008). Design matters \& Packaging: An Essential Primer for Today's competitive Market. Rocket Publishers. First. USA

Dupuis, S. \& Silva, J. (2008). Packaging Design Workbook: the Art and Science of Successful Packaging. Rocket Publishers. First. USA

Derakhshan, S. (2011). History of Chocolate. Agriculture and Food, No. 95. 28-29 
Ebrahimi Rashti, H. (2007). Studying and Prioritizing Effective Factors on Packaging Chocolate Product in Line with boosting Sales Rate of Company (Shomal food Industries Co.) 2007. Islamic Azad University north Tehran Branch: Master of Business Administration

Feyz, D., \& Salahshour, A. (2008). Role of Packaging in Marketing. Semnan University. Semnan, Iran.

Feyz, D., \& Salahshour, A. (2011). Studying Application of Golden Ratio in Packaging Products and Its effect on Purchase Behavior of Consumers. Business Administration Periodical. $2^{\text {nd }}$ Edition. 6 , 113-134

Firouzian, M., \& Hasangholipour,T., \& Estiri, M. (2010). Studying Effectiveness of Packaging Factors on Various Processes of Behavior of Consumers of Food Products. Business Administration Periodical. $1^{\text {st }}$ ed., 3. 125-146

Hawkins, D. L., \& Mothersbaugh, D. L. \& Best, R. J. (2007). Consumer Behavior: Building Marketing Strategy. Mc-Graw Hill. Ney York. $10^{\text {th }}$

Kermaninejad, F. (2006). A Glance at Packaging Design. Karin Publications. Tehran. First

Sharifi, M. (2010). Significance and Role of Packaging Goods at Exports. Standard Monthly, 215. 34-39.

Scctzer, J.R. (2002). The Total Package. 